\title{
Feeding behavior of sheep fed diets with Elaeis guineensis palm kernel meal
}

\section{Comportamento alimentar de ovinos alimentados com dietas contendo farelo de dendê (Elaeis guineensis)}

\author{
Bianca Damasceno Pinho ${ }^{1}$; Aline Fernanda Oliveira Ramos ${ }^{1}$; \\ José de Brito Lourenço Júnior ${ }^{2}$; Cristian Faturi³; André Guimarães Maciel e Silva²; \\ Benjamim de Souza Nahúm ${ }^{4}$; Maria Cristina Manno ${ }^{3}$; Kedson Raul de Souza Lima \\ Luciano Fernandes Sousa ${ }^{5}$; Jamile Andréa Rodrigues da Silva ${ }^{3 *}$; \\ Geisielly Sousa Araújo ${ }^{1}$; Juliana Cristina de Castro Budel ${ }^{1}$
}

\begin{abstract}
In order to evaluate the feeding behavior of sheep fed with diets containing different levels of palm kernel meal (PKM) substituted for corn silage, a metabolic assay was performed on 20 ewes ( 5 treatments $\times 4$ replicates) over $25 \mathrm{~d}$. The animals received corn silage diets with the addition of increasing levels of $\operatorname{PKM}(0,15,30,45$, and $60 \%)$. The following parameters were evaluated: dry matter (DM) intake, neutral detergent fiber (NDF) intake, feeding time, rumination time, idle time, number of merycism mastications per bolus, time spent ruminating each bolus, DM and NDF per bolus, number of ruminated boluses per day, feeding and rumination efficiency, total chewing time, and number of merycism mastications per day. The daily intake of both DM and NDF increased linearly $(\mathrm{P}<0.05)$, and when sheep were fed diets of at least 43.18 and $39.15 \%$ PKM, respectively, the consumption values were significantly different than when sheep were fed diets with $0 \%$ PKM $(\mathrm{P}<0.05)$. In contrast, feeding time declined linearly, and in response to diets with at least $28.05 \%$ PKM, the sheep exhibited significantly different feeding times from those of sheep fed $0 \%$ PKM, with a reduction of 0.0613 percentage points per $1 \%$ increase in PKM. Idle time, rumination time, and rumination time per bolus each exhibited quadratic responses $(\mathrm{P}<0.05)$, and the minimum rumination time per bolus was $44.37 \mathrm{~s}$ with $35.19 \%$ PKM. A quadratic response was also observed for total chewing time and both measures of merycism mastications $(\mathrm{P}<0.05)$. Therefore, we concluded that the inclusion of PKM in the diets of sheep improves some parameters of feeding behavior, and the use of PKM is recommended at DM percentages of up to $40 \%$.
\end{abstract}

Key words: Sheep. Palm kernel meal. Elaeis guineensis. Rumination efficiency. Merycism mastication.

${ }^{1}$ Zootecnistas, Mestres em Ciência Animal, Universidade Federal do Pará, UFPA, Belém, PA, Brasil. E-mail: bianca_damaceno@, yahoo.com.br; ramos.afo@gmail.com; geisielly.sousa@hotmail.com; julianabudel@hotmail.com

2 Profs. Drs., Programa de Pós-Graduação em Ciência Animal, UFPA, Campus Castanhal, Castanhal, PA, Brasil. E-mail: joselourencojr@yahoo.com.br; andregms@gmail.com

3 Profs. Drs., Instituto de Saúde e Produção Animal, Universidade Federal Rural da Amazônia, ISPA/UFRA, Belém, PA, Brasil. E-mail: cristian.faturi@ufra.edu.br; cristina.manno@ufra.edu.br; kraul.lima@gmail.com; jamileandrea@yahoo.com.br

${ }^{4}$ Pesquisador B, Embrapa Amazônia Oriental, Belém, PA, Brasil. E-mail: benjamim.nahum@embrapa.br

5 Prof. Dr., Universidade Federal do Tocantins, UFT, Araguaína, TO, Brasil. E-mail: luciano.sousa@mail.uft.edu.br

* Author for correspondence 


\title{
Resumo
}

\begin{abstract}
Para avaliar o comportamento ingestivo de ovinos alimentados com dietas contendo diferentes níveis de farelo de dendê em substituição à silagem de milho, realizou-se ensaio metabólico, com 20 ovinos fêmeas, cinco tratamentos e quatro repetições, durante 25 dias. Os animais receberam dieta com silagem de milho (SM) e níveis crescentes de inclusão $(0 \%, 15 \%, 30 \%, 45$ e $60 \%)$ de farelo de dendê (FD). Foram avaliados o consumo de matéria seca (CMS) e de fibra detergente neutra (CFDN), tempo em alimentação (TAL), ruminação (TRU) e ócio (TOC), número de mastigações merícicas por bolo (NMM/ bolo), tempo despendido para ruminação de cada bolo (TR/bolo), gramas de MS e FDN por bolo, número de bolos ruminados por dia (NBR/dia), eficiências de ingestão e ruminação, em $\mathrm{g} \mathrm{MS} / \mathrm{hora}$ e g FDN/hora, tempo de mastigação total (TMT), em h/dia, e número de mastigações merícicas por dia (NMM/dia). Os CMS e CFDN aumentaram linearmente $(\mathrm{P}<0,05)$, sendo que a partir de $43,18 \%$ e $39,15 \%$, respectivamente, de inclusão de FD na dieta, os valores de consumo diferiram $(\mathrm{P}<0,05)$ do tratamento com $0 \%$ de inclusão. O TAL reduziu linearmente $(\mathrm{P}<0,05)$, sendo que a partir de $28,05 \%$ de inclusão do subproduto, diferiu do tratamento com $0 \%$, com redução de 0.0613 unidades percentuais, a cada $1 \%$ de inclusão de FD. O TOC e TRU apresentaram efeito quadrático $(\mathrm{P}<0,05)$. O TR/bolo, em segundos, apresentou comportamento quadrático e o valor mínimo foi de 44,37 segundos, no nível de $35,19 \%$ de FD. Observou-se efeito $(\mathrm{P}<0,05)$ quadrático para do TMT e MM, em todas as formas que foram expressas. A inclusão de FD na dieta melhora alguns parâmetros do comportamento ingestivo, sendo recomendada sua utilização até o nível de $40 \%$ na dieta.
\end{abstract}

Palavras-chave: Alimentação. Consumo. Ruminação. Subproduto.

\section{Introduction}

In recent decades, sheep farming has improved in Brazil, and its contribution to the supply of meat, leather, wool, and other products is increasing. The recent progress in nutrition, reproduction, and genetic improvement has also exerted a positive influence on meat and milk production. However, a better understanding of animal behavior is needed in order to better manage food consumption, which would allow farmers to adjust the feeding of animals to improve their performance (CARVALHO et al., 2006; PIRES et al., 2009). To reduce the cost of feeding and to increase profitability, it is necessary to use alternative feeds that improve animal productivity, while also maintaining a high quality of meat and milk (OLIVEIRA et al., 2010) and meeting the nutritional needs of the animals.

In the state of Pará, the significant increase in agroindustry has resulted in an increased availability of residues and byproducts not used by the food and cosmetic industries. These residues can damage ecosystems Ehen dumped in the environment (ABDALLA et al., 2008). However, the cakes and meals produced by the biodiesel industry, for example, have a high potential for use in the feeding of ruminants, considering their elevated protein and ethereal extract concentrations, which characterize them as high-protein, highenergy foods that can meet the nutritional needs of animals (OLIVEIRA et al., 2012). Another byproduct, palm kernel meal (PKM), is obtained during the extraction of palm oil from Elaeis guineensis, through the use of pressure and organic solvents, and although the meal contains a high fraction of cell wall material (CARVALHO et al., 2006), PKM is still considered a high-energy and average-quality food for ruminants.

However, it is necessary to evaluate the feeding behavior of animals with the inclusion of these agroindustry byproducts, since the chemical and physical properties of these foods are different from those of fodder plants and may affect the degradation and transit of food in the gastrointestinal tract (CARVALHO et al., 2006). Through the observation of feeding duration and efficiency, the evaluation of feeding behavior enables us to better understand 
the digestion of foods (MENDONÇA et al., 2004; TREVISAN et al., 2005), including utilization efficiency, absorption efficiency, and rumination conditions (MENDES NETO et al., 2007). Thus, the present study was conducted to evaluate the feeding behavior of sheep fed corn silage diets with different levels of PKM.

\section{Material and Methods}

The experiment was conducted at Embrapa Amazônia Oriental $\left(1^{\circ} 28^{\prime} \mathrm{S} 48^{\circ} 27^{\prime} \mathrm{W}\right)$, Belém, Pará, Brazil, with 20 ten-month-old ewes of no defined breed and with a mean weight of $35 \mathrm{~kg}$. The ewes were distributed in a completely randomized design, with four replicates for each of five treatments. The animals were kept in individual metabolic cages, each with a feeder and drinker, and received diets of corn silage with increasing levels $(0,15,30,45$, and $60 \%)$ of E. guineensis PKM, on a dry matter (DM) basis (Table 1), with water and mineral salt ad libitum. The diets were offered twice a day, at 8:00 a.m. and 5:00 p.m., in amounts adjusted to provide $15 \%$ leftovers.

The PKM used in the present study was a byproduct of organic oil extraction from palm kernel cake (PKC), which was obtained by mechanical extraction. The organic extraction was performed by incubating PKC in an extractor, with hexane, for $1 \mathrm{~h}$. The resulting solution of oil and hexane was kept at $60^{\circ} \mathrm{C}$, in order to recover the hexane and to obtain the palm oil, whereas the solid material, with low oil content, was processed in a solvent extractor for $1 \mathrm{~h}$ to evaporate the residual hexane (palm oil industry, personal communication).

Table 1. Bromatological composition (\%) of experimental corn silage diets with different levels of Elaeis guineensis palm kernel meal (PKM).

\begin{tabular}{|c|c|c|c|c|c|c|}
\hline & \multicolumn{6}{|c|}{ Level of palm kernel meal ${ }^{1}$} \\
\hline & $0 \%$ & $15 \%$ & $30 \%$ & $45 \%$ & $60 \%$ & PKM (\%) \\
\hline Dry matter & 35.40 & 38.00 & 54.73 & 63.34 & 70.8 & 90.5 \\
\hline Organic matter & 95.55 & 95.53 & 95.51 & 95.50 & 95.50 & 95.43 \\
\hline Crude protein & 5.44 & 6.77 & 8.11 & 9.44 & 10.77 & 14.33 \\
\hline Fiber in neutral detergent & 48.93 & 50.64 & 52.34 & 54.05 & 55.75 & 60.30 \\
\hline Fiber in acid detergent & 18.41 & 18.94 & 19.48 & 20.01 & 20.54 & 21.96 \\
\hline Hemicellulose & 31.54 & 32.96 & 34.38 & 35.80 & 37.22 & 41.01 \\
\hline Cellulose & 16.55 & 16.13 & 15.71 & 15.29 & 14.87 & 13.75 \\
\hline Lignin & 1.67 & 2.60 & 3.52 & 4.45 & 5.37 & 7.84 \\
\hline Total carbohydrates & 85.01 & 85.00 & 84.98 & 84.97 & 84.95 & 80.2 \\
\hline Non-fibrous carbohydrates & 36.08 & 33.65 & 31.23 & 28.80 & 26.37 & 19.9 \\
\hline Neutral detergent insoluble protein ${ }^{2}$ & 18.49 & 18.52 & 18.55 & 18.58 & 18.61 & 18.70 \\
\hline Acid detergent insoluble protein ${ }^{2}$ & 10.20 & 9.73 & 9.26 & 8.79 & 8.32 & 7.08 \\
\hline Ethereal extract & 5.10 & 4.47 & 3.84 & 3.21 & 2.58 & 0.9 \\
\hline Total digestible nutrients & 78.32 & 84.16 & 83.06 & 82.42 & 81.01 & --- \\
\hline Ash & 4.45 & 4.47 & 4.49 & 4.50 & 04.52 & 4.7 \\
\hline
\end{tabular}

${ }^{1}$ Dry matter basis; ${ }^{2}$ Level of the replacement of corn silage (CS) by palm kernel meal (PKM)

${ }^{*}$ Percentage of crude protein; ${ }^{3}$ Palm kernel meal. 
The levels of crude protein (CP), ethereal extract (EE), neutral detergent fiber (NDF), and neutral detergent insoluble protein of the experimental diets were measured, using the methods described by Silva and Queiroz (2002), and the percentage of non-fibrous carbohydrates (NFC) and total carbohydrates (TC) were calculated using the equations proposed by Sniffen et al. (1992): NFC $(\%)=100 \%-\mathrm{NDFcp}(\%)-\mathrm{CP}(\%)-\mathrm{EE}(\%)-\mathrm{Ash}$ $(\%)$ and TC $(\%)=100 \%-\mathrm{CP}(\%)+\mathrm{EE}(\%)+\mathrm{Ash}$ $(\%)$.

The experimental period lasted $25 \mathrm{~d}$, with $21 \mathrm{~d}$ for adaptation and $4 \mathrm{~d}$ for data collection. During the first $2 \mathrm{~d}$ of data collection, the feeding behavior of the animals (time spent feeding, ruminating, and idle) was observed visually, every five minutes, by trained observers (BROOM; FRASER, 2010). During the second $2 \mathrm{~d}$ of data collection, we evaluated the intake of both DM and NDF, counted the number of merycism mastications (MM; mastication of ruminal boluses) per bolus, and recorded the time spent ruminating each bolus, using a digital chronometer. For each animal, the MM and ruminating time of three ruminal boluses were recorded at different times of the day (CARVALHO et al., 2006), during periods of peak rumination, i.e., 3:00-6:00 a.m., 11:00 a.m-1:00pm, and 8:00-10:00 p.m.

For each animal, the mean DM and NDF per bolus were calculated from the daily consumption of DM and NDF and number of ruminated boluses, which was calculated from the total rumination time and average ruminating time per bolus (POLLI et al., 1996). The feeding and rumination efficiencies of both DM and NDF were calculated from the daily consumption of DM and NDF and the time spent feeding or ruminating, respectively, and total chewing time and number of MM per day were obtained as described by Bürger et al. (2000).

The data were subject to regression analysis and the significance of the models was determined using the Fisher's test. The data of variables that conformed to linear models were then analyzed, using the Williams' test, in order to determine if the values for sheep under the various PKM treatments were significantly different than those of sheep fed diets without PKM. Statistical procedures were conducted using SAS (2004).

\section{Results and Discussion}

The daily intake of both DM and NDF increased linearly $(\mathrm{P}<0.05)$, and when sheep were fed diets of at least 43.18 and $39.15 \%$ PKM, respectively, the consumption values were significantly different from those observed when sheep were fed diets with $0 \%$ PKM (Williams' test, $\mathrm{P}<0.05$; Table 2). According to Dantas Filho et al. (2007), increased levels of dietary NDF can limit the consumption of DM, and the physical regulation of DM consumption mainly occurs as result of the higher volume of cell wall material, as well as its low density and slower degradation, than of cell contents (NRC, 2001). In the present study, the increase in DM consumption may have resulted from the low granulometry of the PKM and its high transit rate, which reduced its physical effect consumption (GOMES et al., 2012). 
Table 2. Feeding behavior of sheep fed corn silage diets with different levels of Elaeis guineensis palm kernel meal.

\begin{tabular}{|c|c|c|c|c|c|c|c|c|}
\hline & \multicolumn{7}{|c|}{ Level of palm kernel meal } & \multirow[b]{2}{*}{ Regression equation } \\
\hline & $0 \%$ & $15 \%$ & $30 \%$ & $45 \%$ & $60 \%$ & $\mathrm{CV}$ & $\mathrm{R}^{2}$ & \\
\hline DMI (kg/d) & 0.91 & 0.59 & 1.06 & 1.33 & 1.23 & 25.64 & 56.55 & $Y=0.752500+0.009167 * x$ PKM \\
\hline NDFI (kg/d) & 0.44 & 0.32 & 0.56 & 0.72 & 0.68 & 24.72 & 62.82 & $\mathrm{Y}=0.36900+0.00593 * \mathrm{x}$ PKM \\
\hline $\mathrm{FT}(\mathrm{h} / \mathrm{d})$ & 4.3 & 4.2 & 2.8 & 2.9 & 3.2 & 76.48 & 63.41 & $Y=10.649514-0.061315 * x$ PKM \\
\hline $\mathrm{RT}(\mathrm{h} / \mathrm{d})$ & 9.0 & 7.0 & 6.2 & 7.7 & 7.5 & 53.11 & 71.44 & $\begin{array}{l}\mathrm{Y}=22.127520-0.322915^{*} \mathrm{x} \mathrm{PKM}+ \\
0.004749 \times \mathrm{PKM}^{2}\end{array}$ \\
\hline IT (h/d) & 10.5 & 12.7 & 14.8 & 13.3 & 13.2 & 32.91 & 87.07 & $\begin{array}{l}Y=26.426974+0.490223 * x \text { PKM }- \\
0.006515 \times \mathrm{PKM}^{2}\end{array}$ \\
\hline NRB (bolus/d) & 655.5 & 849.7 & 584.0 & 600.3 & 610.0 & 26.9 & - & $\mathrm{Y}=659,90^{\mathrm{ns}}$ \\
\hline $\mathrm{TCT}(\mathrm{h} / \mathrm{d})$ & 12.5 & 8.3 & 7.2 & 9.2 & 9.7 & 17.22 & 84.47 & $\begin{array}{l}\mathrm{Y}=12.125143-0,266619 * \mathrm{x} \mathrm{PKM}+ \\
0.003916 \times \mathrm{PKM}^{2}\end{array}$ \\
\hline RT/bolus (s) & 52.68 & 48.57 & 42.40 & 46.57 & 48.26 & 21.27 & 83.47 & $\begin{array}{l}Y=52.997643-0.489852 * x \mathrm{PKM}+ \\
0.006960 \times \mathrm{PKM}^{2}\end{array}$ \\
\hline
\end{tabular}

$\mathrm{DMI}=$ dry matter intake; NDFI = neutral detergent fiber intake; FT = feeding time; $\mathrm{RT}=$ rumination time; $\mathrm{IT}=\mathrm{idle}$ time; $\mathrm{NRB}=$ number of ruminated boluses; $\mathrm{TCT}=$ total chewing time; $\mathrm{RT} /$ bolus $=$ mean rumination time per bolus.

* Significance at $5 \%$ probability level $(\mathrm{P}<0.05)$ by F-test; ns = non-significant $(\mathrm{P}>0.05)$.

In contrast, feeding time declined linearly, and in response to diets with at least $28.05 \%$ PKM, the sheep exhibited feeding times that were significantly different from those of sheep fed $0 \%$ PKM, with a reduction of 0.0613 percentage points per $1 \%$ increase in PKM. This decrease probably occurred because the higher daily DM consumption, associated with lower daily ingestion and rumination time, owing to use of the experimental diets led to a reduction in feeding time. In contrast, Carvalho et al. (2006) reported that the decreased feeding time observed in sheep fed diets with PKC was probably due to reduced DM consumption. Therefore, since the DM consumption of the experimental diets increased with the inclusion of PKM, we expected to observe an increase in feeding, but such an increase did not occur. However, the increase in DM consumption observed in the present study may be attributed to the elevation of DM in the experimental diets, with the inclusion of PKM (Table 1), but not necessarily of feeding time.

In addition, the reduction in feeding time also resulted in increased idle time, which exhibited a quadratic response $(\mathrm{P}<0.05)$, with a maximum of 14 $\mathrm{h} / \mathrm{d}$ with the inclusion of $37.62 \%$ of DM on the diet.
These results are in accordance with those of Pires et al. (2009), who observed significant changes in DM consumption and increased idle time in sheep fed silage with cassava meal.

A quadratic response was also observed for rumination time $(\mathrm{P}<0.05$; Table 2$)$, with a minimum of $6.4 \mathrm{~h} / \mathrm{d}$ with the inclusion of $34.00 \%$ PKM. According to Carvalho et al. (2006), rumination is a physiological response deployed according to the reduction of the feeding time, in order to make better use of the food, and this fact is corroborated by the values of feeding and rumination time observed in the present study.

Moreover, the inclusion of PKM was associated with an increase in NDF, which probably explains the increase in rumination time, since changes in feeding and rumination times have been associated with changes in levels of dietary fiber (CARVALHO et al., 2006; CORREIA et al., 2012;).

The number of boluses ruminated per day was not affected by the addition of PKM $(\mathrm{P}>0.05)$, and its mean value was 659.90 ruminated boluses per day. However, the rumination time per bolus exhibited a quadratic response, with a minimum of 
$44.37 \mathrm{~s}$ at $35.19 \%$ PKM (Table 2). The observed mean number of boluses ruminated per day was similar to that observed by Pires et al. (2009), which was 613.5 per day, but lower than that observed by Carvalho et al. (2006), which was 839.4 per day.

A quadratic response was also observed for total chewing time $(\mathrm{P}<0.05)$, with an estimated minimum value of $7.58 \mathrm{~h} / \mathrm{d}$, with the inclusion of $34.04 \%$ PKM. According to Bianchini et al. (2007), the addition of fiber to diets stimulates chewing activity, which validates the higher mean values of total chewing time in the treatments with higher levels of fiber (Table 1). However, Carvalho et al. (2004) did not observed differences among diets composed of 15 and 30\% PKC and observed total chewing times of 13.10 and $12.96 \mathrm{~h} / \mathrm{d}$, respectively, which are greater than the values we observed in response to 15 and 30\% PKM, which were 8.3 and $7.2 \mathrm{~h} / \mathrm{d}$.

Both measures of MM exhibited quadratic responses $(\mathrm{P}<0.05)$ with estimated minimum values of 51.16 MM/bolus and 32,002.44 MM/ day, with the inclusion of 33.6 and $35.06 \%$ PKM, respectively (Table 3). Carvalho et al. (2006) found that the number of MM per bolus was not affected by the replacement of Tifton grass hay with PKC $(15,30$, and $45 \%)$ in the diets of goats and observed a mean of $73.55 \mathrm{MM} /$ bolus, which was greater than the value of $58.92 \mathrm{MM} /$ bolus observed in the present study. However, the mastication values reported by Carvalho et al. (2006) for diets with 15 and 30\% PKC (42,590.38 and 43,393.09 MM/d, respectively) were similar to those observed in the present study, with the inclusion of 45 and $60 \%$ PKM.

Regression analysis revealed that both feeding $(\mathrm{DM} / \mathrm{h})$ and rumination (NDF/h) efficiency increasing linearly in response to the addition of PKM ( $<<0.05$; Table 3). However, Carvalho et al. (2008) evaluated the addition of cocoa meal $(0,10$, 20 , and $30 \%$ ) to diets for sheep and observed no significant differences on feeding and rumination efficiency in response to similar consumption of DM and NDF between the diets, with means of 1.38 and $0.60 \mathrm{~kg}$, respectively. In the present study, the increase in DM and NDF intake explains the observed feeding and rumination efficiencies, which are directly related to overall consumption.

Table 3. Feeding and rumination of sheep fed corn silage diets with different levels of Elaeis guineensis palm kernel meal.

\begin{tabular}{|c|c|c|c|c|c|c|c|c|}
\hline & \multicolumn{8}{|c|}{ Level of palm kernel meal } \\
\hline & $0 \%$ & $15 \%$ & $30 \%$ & $45 \%$ & $60 \%$ & $\mathrm{CV}$ & $\mathrm{R}^{2}$ & Regression Equation \\
\hline \multicolumn{9}{|c|}{ Feeding efficiency } \\
\hline $\mathrm{DM}(\mathrm{g} / \mathrm{h})$ & 210.9 & 142.9 & 373.9 & 463.7 & 393.9 & 27.16 & 65.29 & $Y=179.781500+4.577817 *^{*} \mathrm{PKM}$ \\
\hline NDF $(g / h)$ & 101.7 & 76.5 & 198.4 & 251.4 & 217.8 & 26.21 & 71.66 & $\mathrm{Y}=87.758000+2.714450 * \mathrm{x}$ PKM \\
\hline \multicolumn{9}{|c|}{ Rumination efficiency } \\
\hline $\mathrm{DM}(\mathrm{g} / \mathrm{h})$ & 101.1 & 85.0 & 170.7 & 181.5 & 159.8 & 28.38 & 60.24 & $\mathrm{Y}=96.891500+96.891500 * \mathrm{x}$ PKM \\
\hline $\mathrm{NDF}(\mathrm{g} / \mathrm{h})$ & 48.7 & 45.5 & 90.6 & 98.4 & 88.3 & 27.49 & 69.09 & $\mathrm{Y}=47.910500+0.881300 * \mathrm{x}$ PKM \\
\hline \multicolumn{9}{|c|}{ Merycism mastications } \\
\hline MM/bolus & 71.5 & 55.1 & 49.3 & 57.9 & 60.8 & 17.16 & 87.16 & $\begin{array}{l}Y=70.215071-1.131093 * x \mathrm{PKM}+ \\
0.016791 \times \mathrm{PKM}^{2}\end{array}$ \\
\hline $\mathrm{MM} / \mathrm{d}$ & 66.839 & 37.154 & 30.945 & 42.155 & 44.639 & 36.09 & 85.25 & $\begin{array}{l}Y=6390053571-1819.940776^{*} x \\
P K M+25.954619 x \text { PKM }^{2}\end{array}$ \\
\hline \multicolumn{9}{|c|}{ Rumination } \\
\hline DM (g/bolus) & 1.4 & 1.1 & 2.0 & 2.3 & 2.1 & 31.37 & 62.10 & $\mathrm{Y}=1.337500+0.016600 * \mathrm{x}$ PKM \\
\hline NDF (g/bolus) & 0.7 & 0.6 & 1.0 & 1.2 & 1.1 & 30.40 & 73.94 & $Y=0.656000+0.010617 * x$ PKM \\
\hline
\end{tabular}

$\mathrm{DM}=$ Dry matter; $\mathrm{NDF}=$ neutral detergent fiber; $\mathrm{MM}=$ Merycism mastications.

* Significance at $5 \%$ probability level $(\mathrm{P}<0.05)$ by F-test. 
The fiber content and physical shape of diets are the main factors that affect rumination time (SILVA; NEUMANN, 2012). In the present study, increased NDF from the addition of PKM resulted in improved rumination efficiency, which increased linearly $(\mathrm{P}<0.05)$ and was significantly higher in sheep fed diets with at least 41.74 and $31.62 \%$ PKM, respectively, than in those fed diets with $0 \%$ PKM. The observed increase in DM and NDF consumption with higher levels of PKM reflected the incremental improvement of rumination efficiency and rumination, in agreement with Pires et al. (2009), who suggested that the higher rumination of cassava meal silage ( $1.86 \mathrm{~g} \mathrm{DM}$ /bolus and $0.75 \mathrm{~g} \mathrm{NDF} /$ bolus) was associated with higher DM consumption.

The values of NDF per ruminated bolus with 0 and $15 \%$ PKM was 0.7 and $0.6 \mathrm{~g}$, respectively, which are lower than the values of 1.37 and 1.45 $\mathrm{g}$ reported by Carvalho et al. (2006) for diets with 0 and $15 \%$ PKC. However, the lower values in the present study may have resulted from lower levels of dietary NDF (48.9 and 50.6\%, respectively) than those in the diets used by Carvalho et al. (2006) (80.47 and $79.09 \%$, respectively).

\section{Conclusions}

In the present study, we found that the feeding behavior of sheep was significantly affected by the addition PM to a corn silage diet. The addition of PKM resulted in increased nutrient consumption, and the inclusion of up to 40\% PKM (dry matter basis) increased both feeding and rumination efficiency and did not compromise the productive performance of the animals.

\section{Acknowledgements}

The present study was supported by a Master's degree scholarship from the Coordination for the Improvement of Higher Education Personnel
(CAPES) Foundation, Ministry of Education, Brazil; by PROCAD - Novas Fronteiras 50400002 from CAPES; and by PECUS (SEG: 01.10.06.001.07.02) from Embrapa.

\section{References}

ABDAlLA, A. L.; SILVA FILHO, J. C.; GODOI, A. R.; CARMO, C. A.; EDUARDO, J. L. P. Utilização de subprodutos da indústria de biodiesel na alimentação de ruminantes. Revista Brasileira de Zootecnia, Viçosa, MG, v. 37, p. 234-241, 2008. Número Especial.

BIANCHINI, W.; RODRIGUES, E.; JORGE, A. M.; ANDRIGHETO, C. Importância da fibra na nutrição de bovinos. REDVET. Revista Electrónica de Veterinária, Andalucía, v. 8, n. 2, p. 1695-7504, 2007.

BROOM, D. M.; FRASER, A. F. Comportamento $e$ bem-estar de animais domésticos. Barueri: Manole, 2010. 438 p.

BÜRGER, P. J.; PEREIRA, J. C.; QUEIROZ, A. C.; SILVA, J. F. C.; VALADARES FILHO, S. C.; CECON, P. R.; CASALI, A. D. P. Comportamento ingestivo em bezerros holandeses alimentados com dietas contendo diferentes níveis de concentrado. Revista Brasileira de Zootecnia, Viçosa, MG, v. 29, n. 1, p. 236-242, 2000.

CARVAlHO, G. G. P.; PIRES, A. J. V.; SILVA, F. F.; VELOSO, C. M.; SILVA, R. R.; SILVA, H. G. O.; BONOMO, P.; MENDONÇA, S. S. Comportamento ingestivo de cabras leiteiras alimentadas com farelo de cacau ou torta de dendê. Pesquisa Agropecuária Brasileira, Brasília, v. 39, n. 9, p. 919-925, 2004.

CARVALHO, G. G. P.; PIRES, A. J. V.; SILVA, R. R.; RIBEIRO, L. S. O.; CHAGAS, D. M. T. Comportamento ingestivo de ovinos Santa Inês alimentados com dietas contendo farelo de cacau. Revista Brasileira de Zootecnia, Viçosa, MG, v. 37, n. 4, p. 660-665, 2008.

CARVALHO, G. G. P.; PIRES, A. J. V.; SILVA, R. R.; VELOSO, C. M.; SILVA, H. G. O. Comportamento ingestivo de ovinos alimentados com dietas compostas de silagem de capim-elefante amonizada ou não e subprodutos agroindustriais. Revista Brasileira de Zootecnia, Viçosa, MG, v. 35, n. 4, p. 1805-1812, 2006. Suplemento.

CORREIA, B. R.; OLIVEIRA, R. L.; JAEGER, S. M. P. L.; BAGALDO, A. R.; CARVALHO, G. G. P.; OLIVEIRA, G. J. C.; LIMA, F. H. S.; OLIVEIRA, P. A. Comportamento ingestivo e parâmetros fisiológicos de novilhos alimentados com tortas do biodiesel. Archivos de Zootecnia, Córdoba, v. 61, n. 233, p. 79-89, 2012. 
DANTAS FILHO, L.A.; LOPES, J. B.; VASCONCELOS, V. R.; OLIVEIRA, M. E.; ALVES, A. A.; ARAÚJO, D. L. C.; CONCEIÇÃO, W. L. F. Inclusão de polpa de caju desidratada na alimentação de ovinos: desempenho, digestibilidade e balanço de nitrogênio. Revista Brasileira de Zootecnia, Viçosa, MG, v. 36, n. 1, p. 147-154, 2007.

GOMES, P. G.; BORGES, BORGES, A. L. C. C.; BORGES, I.; MACEDO JUNIOR, G. L.; SILVA, A. G. M.; PANCOTI, C. G. Efeito do tamanho de partícula do volumoso e da frequência de alimentação sobre o consumo e a digestibilidade em ovinos. Revista Brasileira de Saúde e Produção Animal, Salvador, v. 13, n. 1, p. 137-149, 2012.

MENDES NETO, J.; CAMPOS, J. M. S.; VALADARES FILHO, S. C.; LANA, R. P.; QUEIROZ, A. C.; EURCLYDES, R. F. Consumo, digestibilidade, desempenho, desenvolvimento ponderal e economicidade de dietas com polpa cítrica em substituição ao feno de capim-tifton 85 para novilhas leiteiras. Revista Brasileira de Zootecnia, Viçosa, MG, v. 36, n. 3, p. 626-634, 2007.

MENDONÇA, S. S.; CAMPOS, J. M. S.; VALADARES FILHO, S. C.; VALADARES, R. F. D.; SOARES, C. A.; LANA, R. P.; QUEIROZ, A. C.; ASSIS, A. J.; PEREIRA, M. L. A. Comportamento ingestivo de vacas leiteiras alimentadas com dietas à base de cana-de-açúcar ou silagem de milho. Revista Brasileira de Zootecnia, Viçosa, MG, v. 33, n. 3, p. 723-728, 2004.

NATIONAL RESEARCH COUNCIL - NRC. Nutrient requirements of dairy cattle. Washington: National Academic of Sciences, 2001. 381 p.

OLIVEIRA, J. B.; PIRES, A. J. V.; CARVALHO, G. G. P. RIBEIRO, L. S. O.; CRUZ, J. F.; SILVA, F. F. Subprodutos industriais na ensilagem de capimelefante para cabras leiteiras: consumo, digestibilidade de nutrientes e produção de leite. Revista Brasileira de Zootecnia, Viçosa, MG, v. 39, n. 2, p. 411-418, 2010.
OLIVEIRA, R. L.; LEÃO, A. G.; RIBEIRO, O. L.; BORJA; M. S.; PINHEIRO, A. A.; OLIVEIRA, R. L.; SANTANA, M. C. A. Biodiesel industry by-products used for ruminant feed. Revista Colombiana de Ciencias Pecuarias, Medellin, v. 25, n. 4, p. 625-638. 2012.

PIRES, A. J. V.; CARVALHO, G. G. P.; GARCIA, R.; CARVALHO JUNIOR, J. N.; RIBEIRO, L. S. O.; CHAGAS, D. M. T. Comportamento ingestivo de ovinos alimentados com silagens de capim-elefante contendo casca de café, farelo de cacau ou farelo de mandioca. Revista Brasileira de Zootecnia, Viçosa, MG, v. 38, n. 8, p. 1620-1626, 2009.

POLLI, V. A.; RESTLE, J.; SENNA, D. B. D.; ALMEIDA, S. R. S. D. Aspectos relativos à ruminação de bovinos e bubalinos em regime de confinamento. Revista Brasileira de Zootecnia, Viçosa, MG, v. 25, n. 5, p. 987-993, 1996.

SILVA, D. J.; QUEIROZ, C. Análise de alimentos: métodos químicos e biológicos. Viçosa, MG: Universidade Federal de Viçosa, 2002. 235 p.

SILVA, M. R. H.; NEUMANN, M. Fibra efetiva e fibra fisicamente efetiva: conceitos e importância na nutrição de ruminantes. FAZU em Revista, Uberaba, n. 9, p. 69-84, 2012.

SNIFFEN, C. J.; O'CONNOR, J. D.; VAN SOEST, P. J.; FOX, D. G.; RUSSELL, J. B. A net carbohydrate and protein system for evaluating cattle diets. II. carbohydrate and protein availability. Journal of Animal Science, Champaign, v. 70, n. 11, p. 3562-3577, 1992.

STATISTICAL ANALYSIS SYSTEM INSTITUTE SAS. SAS Institute. Statistical analysis system: user's guide. Cary: SAS Institute, 2004.

TREVISAN, N. B.; QUADROS, F. L. F.; SILVA, A. C. F. da; BANDINELLI, D. G.; MARTINS, C. E. N. Efeito da estrutura de uma pastagem hibernal sobre o comportamento de pastejo de novilhos de corte. Revista Brasileira de Zootecnia, Viçosa, MG, v. 34, n. 3, p. 774780, 2005. 